\title{
Early childhood and kindergarten teachers competences: gap between text and context
}

\author{
R.A. Rahma \\ Faculty of Education Universitas Negeri Surabaya \\ Teacher Education - Education of Early childhood and kindergarten \\ Surabaya, Indonesia \\ rezka.arina@gmail.com
}

\begin{abstract}
- the aims of this research are to describe and analyze: (1) Basic training program implementation for Early Childhood and Kindergarten teachers and (2) Early Childhood and Kindergarten teacher's competences before and after the training program implementation. This research uses a quantitative approach with population of 500 teachers in Surabaya that participated in the training program. The respondents were 131 people consist of 90 women and 41 men under graduated educational background. The results of this study are: (1) the implementation of the basic training program for teachers in Surabaya is a success program, which average value of 3.09 and (2) The competence of Early Childhood and Kindergarten teachers increased by $17.3 \%$ after participating the training. These are the result of research that the researcher did, that the improvement of the competence of Early Childhood and Kindergarten teachers can be affected by several things including educational level, teaching experience, and training participation.
\end{abstract}

Keywords-component; Early Childhood and Kindergarten teachers; teacher's competences; the basic training program

\section{INTRODUCTION}

All families, educators, and the larger society hope that children will grow up better in school and go on to satisfying and productive lives [17]. Teacher's in Early Childhood and Kindergarten has an important role as a person who is responsible for the students' development process [12]. Teachers are not the sole determinant in optimizing child development, but they have a significant role in providing stimuli for children' growth [14]. Teachers for early childhood and kindergarten are different with primary or secondary schools' teacher, because their main task is to indicate the problems related to the children' growth and development as early as possible, so teacher can give an appropriate treatment to optimize children' growth and development [9]. "Reference by [17] which requires four competencies for a teacher; (1) personality, (2) pedagogic, (3) professional and (4) social".

However, the fact in the field shows that many kindergarten' teachers cannot fulfill the professionalism requirement; their qualifications and competences are far away from the standards that had been set before [2]. On the other hand, the conditions in the field also show that many kindergartens' teachers perform their duties over the authority. Moreover, it is often find that kindergarten' teachers from junior high school and they hold as the main teacher of the
Early Childhood and Kindergarten institution. Based on these conditions, an effort is needed to ensure that all teachers in early childhood education have authority in accordance with the competence and qualifications.

The recruitment process of Early Childhood and Kindergarten teacher is no longer to looking for competence qualifications but rather to the willingness to be an Early Childhood and Kindergarten teacher. This is due to the lack of compatible teachers' candidate qualifications, while the field demands of Early Childhood and Kindergarten teacher is high. As the result, many Early Child-hood and Kindergarten teachers are not compatible to the expected competencies. To handle this problem it is necessary to upgrade the kindergarten teacher. Appropriate competence will help them execute their duties as an Early Childhood and Kindergarten teachers.

Previous study by [5] reveals that one of the characteristics of the education crisis in Indonesia is that teachers have not been able to demonstrate adequate performance (work performance). It shows that the performance of teachers has not been supported by the adequate competences; therefore, a comprehensive effort is needed to improve teachers' competence. Some efforts that can be applied to improve teachers' performance are by inviting the teachers in the training program and creating a conducive working climate in the school environment, with a better knowledge and supported by the environment, it is expected to help teachers performance in performing their duties.

Based on the explanation above, it is necessary to conduct research on the basic training program to improve the Early Childhood and Kindergarten teacher's competences. The purpose of this study is to describe and analyze: (1) the implementation of basic training programs for Early Childhood and Kindergarten teachers in Surabaya and (2) the competence of Early Childhood and Kindergarten teachers in Surabaya before and after attending basic training programs.

\section{METHOD}

This research uses quantitative approach, ex-post facto type with One Group-Pretest-Posttest De-sign. This design has a weakness. For example it does not comparing the results of competency tests with the controlling group which in the context of this study is a group of early childhood teachers that does not follow the basic training program. 
Ex-post facto research is an "after-fact" study, conducted after the variation of the studied variables. It is determined on the natural occurrence that has taken place. Thus, the researchers did not execute treatment on the independent variables.

This study often called comparative causal, because it intends to examine the causal and influence relations between independent and dependent variables [20]. In the causal comparative research, the researcher examines how the independent variables are affected by the dependent variables and involves cause and effect relationships between the variables [7]. Both of the studies focused on the relationship of variables and tested the hypothesis, but in the ex-post facto research, the independent variables occurred naturally, there is no conditioning. In the other case, the experiment is involved the independent variable conditioning as desired by the researcher.

As stated by [4]: "The designation ex post facto, from Latin for "after the fact," indicates that ex post facto research is conducted after variation in the variable of interest that has already been determined in the natural course of events. This method called causal comparative because its purpose is to investigate cause-and-effect relationships between independent and dependent variables. Researchers use it in situations that do not permit the randomization and manipulation of variables characteristic of experimental research. Thus, many of the basic rationale for experimental and ex post facto is the same. They both investigate relationships among variables and test hypotheses."

[3] noted that instead of taking groups that are equivalent and subjecting them to different treatments to determine differences in the dependent variables, an ex post facto experiment begins with groups that are already different in some respect and searches in retrospect for factors that brought about those differences. As has been mentioned, the design in this study is one-group-pretest-posttest, which used a onegroup experimental design with two measurements on the dependent variables before and after an event on the independent variable that occurs naturally in the basic training program for Early Childhood and Kindergarten teacher.

The sampling technique used in this research is simple random sampling by Slovin formula. Slovin's formula is given by [16]:

$$
n=\frac{N}{1+N e^{2}}
$$

The samples in this research is 131 people. This research was conducted in Surabaya City. The ata were collected by questionnaire, test, observation, and documentation. Analysis data is descriptive statistic and test.

\section{RESULTS AND DISCUSSION}

\section{A. The Training Program Implementation}

Based on the research and documentation study, the implementation of this training program can be classified as a "good" program. The competence of participants is "very good" and the result of hypothesis test shows, implementation of the training program proved to have an effect to the competence of Early Childhood and Kindergarten teachers. However, this training program implementation has not conducted yet to the needs analysis results. The training program is implemented based on Indonesian ministries of education and culture policy, allegedly for Early Childhood and Kindergarten teachers does not have the required ability in the Early Childhood and Kindergarten teacher standard. Therefore, the problem or the real needs for Early Childhood and Kindergarten teacher should be known first through the study of needs analysis. Johnson formulated that training was conducted to answer the question of "what problem can be solved by training?" The Early Childhood and Kindergarten teacher problem will not be clearly identified without conducting any needs analysis.

Reference by [21] explains training stages include: (1) assessment of training needs (need assessment), which aims to collect information to determine whether a training program is required or not; (2) the aim of training programs development is design training environment and training methods. It is to achieve the training objectives; (3) evaluation of the training program aims to assess whether the training has achieved the expected goals. The existence of these stages indicates that training program must be completely designed based on the teacher needs.

Before setting up the training program researchers must describe reinforces that needs an analysis of the training participants, as well as in the implementation of basic education for Early Childhood and Kindergarten teacher as the object of this study. Lack of Early Childhood and Kindergarten teacher competences could not be detected clearly without the analysis of needs, even though the Early Childhood and Kindergarten teacher pre-test has been done in Surabaya as the object of this study. Pre-test only detected the advantages and disadvantages of the training participants based on written test of multiple-choice objective form. It certainly could not observe the training participants competence' of kindergarten teachers comprehensively. Neither personal professional, pedagogic, nor social competence based on real performance in Early Childhood and Kindergarten institutions. The result of the research is classified as a "good" program, the competence of participants is "very good" and the result of hypothesis test shows the implementation of the training program proved to have an effect to the competence of Early Childhood and Kindergarten teachers. However, this training program implementation has not conducted the needs analysis results. The training program is implemented based on Indonesian ministries of education and culture policy, allegedly for Early Childhood and Kindergarten teachers does not have the required ability for Early Childhood and Kindergarten teacher standard. Therefore, the problem or the real needs for Early Childhood and Kindergarten teacher should be known first through the study of needs analysis. Johnson (Marzuki, 2010) formulated that training was conducted to answer the question of what problem can training solved. The Early Childhood and Kindergarten teacher problem will not be clearly identified without conduct any needs analysis. 
[21] explains training stages which include: (1) assessment of training needs (need assessment), which aims to collect information to determine whether a training program is required or not. (2) training programs development, aiming to design training environment and training methods, needed to achieve the training objectives; (3) evaluation of the training program aims to assess whether the training has achieved the expected goals. The existence of these stages indicates that training program must be completely designed based on the teachers' needs.

The description above reinforces that needs analysis of the training participants should be done before setting up the training program, as well as in the implementation of basic education for Early Childhood and Kindergarten teacher as the object of this study. Lack of Early Childhood and Kindergarten teacher competences could not be detected clearly without the analysis of needs, even though the Early Childhood and Kindergarten teacher pre-test has been done in Surabaya as the object of this study. Pre-test only detected advantages and disadvantages of the training participants based on written test of multiple-choice objective form. It certainly could not observe the training participants competence to kindergarten teachers comprehensively, neither personal professional, pedagogic, nor social competence based on real performance in Early Childhood and Kindergarten institutions.

\section{B. Early Childhood and Kindergarten Teacher Competence}

Descriptively, the findings of the research indicate that the competence of Early Childhood and Kindergarten teachers before the training is classified as "good enough" with the average value of $63.63 \%$,. After participating the training, the value moves to "very good" with the average value of $80.94 \%$, which means increased by $17.3 \%$. The highest point increase lies in professional competence $(25.24 \%)$, then pedagogic $(21.11 \%)$, social $(10.48 \%)$, and last personality competence $(10.15 \%)$.

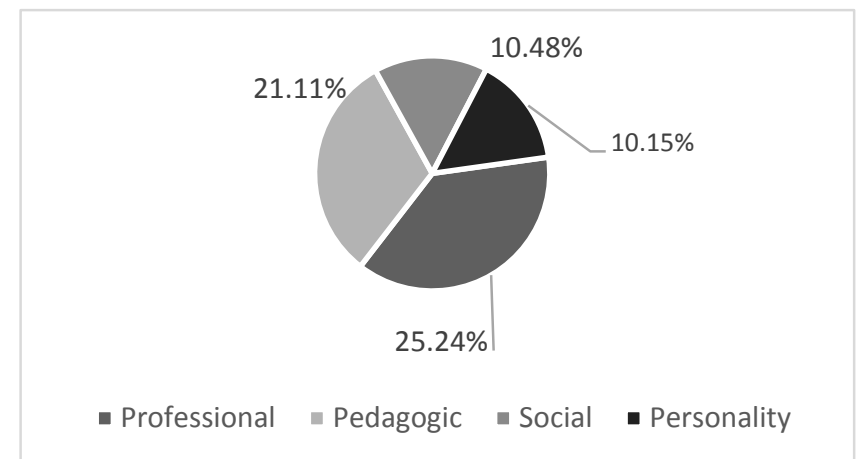

Figure 1. Kindergarten Teacher Competence

The findings of this study are quite logic because the basic assumption of this training program is determined on professional and pedagogic, social and personality in Early Childhood and Kindergarten institution respectively. The early years can provide the basis for a long, healthy life span [13]

The competence enhancement of Early Childhood and Kindergarten teachers after attending the basic training shows that the basic training is quite effective in improving the performance of the teachers to improve their duties and work affectivity [8]. It means, the basic training that has been implemented has proven to be effective as an activity designed to improve the Early Childhood and Kindergarten teacher's performance. As proposed by [13] "those activities which are designed to improve human performance on the job the employee is present to do or is being here to do ". Simamora similarly pointed out in [6] training is indeed as a series of activities designed to enhance the skills, knowledge, experience, or an individual's attitude transformation. As also confirmed in Presidential Instruction No. 15 of 1974, basic teacher training is an integral part of education to improve skills beyond the formal education system. In a short term, [18] reinforces that:

"Training is defined as the systematic acquisition of skill, rules, concept, or attitudes that result in improved performance in the work situation. In some of these instances such as direct on the job training. The instructional environment is similar or identical to the on the job environment. In other instances the training occurs in a place far removed from the actual worksite".

\section{Hypothesis Result}

Hypothesis test results also reinforce the findings above, the implementation of basic teacher training program effects on the competence of training program participants with $t$ of 57.329 and $\mathrm{p}=0.000<0.05$, which means quite significant. This means that there is a significant difference in the Early Child-hood and Kindergarten teacher competences before the training and after the training.

The results of that study are in line with the results of Yulindrasari (2011) that there is a significant difference in the professional competence of Early Childhood and Kindergarten teachers in term of their educational background. Successfulness measurement of teacher basic training in improving the professional competence of Early Childhood and Kindergarten teachers show that there is a significant increase point in the professional competence of Early Childhood and Kindergarten teachers after training.

The results of this study are also in line with the research results of [5]. The study reveals the influence of educational factors and teacher leadership training on teacher performance of $33 \%$, while work condition factor to teacher performance is $67 \%$. Simultaneously, factor of education and teaching skill leadership training with work condition is $57 \%$.

[11] also proves that the training can improve teacher's competence. The results of his research: (1) The ability of Chemistry Teachers in understanding the students receive the "enough" category, with the percentage of $77.5 \%$; (2) teacher's chemistry ability to design and implement the learning process with "very good" category, with $94 \%$ (3) The influence of basic training on teacher competence increased by $29.2 \%$ after the training.

The research by [15] also strengthens the results of this study. They found: (1) the implementation of the training program based on "lesson study" had an effect on increasing 
social competence of science teacher in Public Senior High School 4 of Singaraja; and (2) the implementation of the training program based on "lesson study" had an effect on increasing personality competence of the science teacher in that school.

\section{CONCLUSION}

The implementation of the training program effects on the competence of training program participants, $\mathrm{t}=-57.329$ and $\mathrm{p}$ $=0.000<0.05$. This means there is a significant difference in the Early Childhood and Kindergarten teacher's competences before and after the training. Some things that affect the competences are the level of teacher education, teaching experience, and participation in the training program.

[1] Ary, D., Lucy C.J. \& Chris S. (Ed.). "Introduction to Research in Education $8^{\text {th }}$ Edition". USA: Wadsworth. 2010

[2] Belm, Dun. "Early Childhood Educator Competencies".Unpublished. 2008.

[3] Cohen, L., Manion, L. \& Morison, K.. "Research Methods in Education". London: Routledge Falmer. 2000.

[4] Donald, Ary., Lucy Cheser Jacobs, Asghar Razavieh. Introduction to Research Education: WARDSWORTH. Australia. 2010.

[5] Hasanah, D. S. "Pengeruh Pendidikan Latihan (Diklat) Kepemimpinan Guru dan Iklim Kerja terhadap Kinerja Guru Sekolah Dasar Se Kecamatan Babakancikao Kabupaten Purwakarta". Jurnal Penelitian Pendidikan. 2010. Vol 11 Number. 2 P. 91-94.

[6] Kamil, Mustofa. Model Pendidikan dan Pelatihan; Konsep dan Aplikasi. Alfabeta: Bandung. 2010.

[7] Leedy, P. \& Ormrod, J. "Practical research: Planning and design (7th ed.)". Upp'er Saddle River, NJ: Merrill Prentice Hall. Thousand Oaks: SAGE Publications.2001.
[8] Martha, Z. Beck, M. and Ivelisse. "Critical Issues in Early Childhood Professional Development". Brookes Publishing Company: Baltimore. 2005.

[9] Miller, E and Almond, J. "Crisis in the Kindergarten Why Children Need to Play in Schoo"l. :College park: Alliance for childhoood. 2009.

[10] Peraturan Menteri Pendidikan Nasional Republik Indonesia Nomor 58 Tahun 2009. Tentang Standar Pendidikan Anak Usia Dini.

[11] Pulungan, Intan. 2013. “Analisis Kompetensi Guru Pasca Dik-lat Guru Mata Pelajaran Kimia Tingkat Madrasah Aliyah Se Sumatera Utara". Laporan Penelitian. diunduh dari http://sumut.kemenag.go.id/ 5/7/2013 pada tgl. 20 Mei 2015

[12] Samuelsson, I. P and Kaga, Yoshie. The contribution of early chilhood education to suistainable society. Paris:Unesco. 2008.

[13] Shonkoff, P, J and Meisels, J, S. "Early chilhood intervention: Evaluation of concept Handbook". Cambridge: University Press. 1990.

[14] Sujiono, Nurani Yuliani. Konsep Dasar Pendidikan Anak Usia Dini. Jakarta: PT. Macanan Jaya Cemerlang. 2009.

[15] Suratni, I. W. Sadia, dan Putu Budi Adnyana. "Pengaruh Diklat Berbasis Lesson Study Terhadap Peningkatan Kompetensi Sosial Dan Kompetensi Kepribadian Guru Sains Serta Efeknya Terhadap Sikap Ilmiah Siswa" e-Journal Program Pascasarjana Universitas Pendidikan Ganesha Program Studi IPA, Volume 4. 2014

[16] Tejada, J.J and Punzalan, R.B.J. "On the Misuse of Slovin's Formula"

[17] The National Association for the Education of Young Children. "Developmentally Appropriate Practice in Early Childhood Programs Serving Children from Birth through Age 8". 2009. Unpublised The Philippine Statistician. Vol. 61, No. 1. pp. 129-136. 2012.

[18] Tight, Malcolm. Key Concept in Adult Education And Training. Routledge Falmer: USA and Canada. 2002.

[19] Undang-Undang SISDIKNAS.No. 20 Tahun 2003. Sistem pendidikan nasional. Media Centre: Surabaya.

[20] Williams, C. "Research Methods" Journal of Business \& Economic Research - March 2007 Vol. 5 Number 3 P 65

[21] R. K. Russell and T. Petrie, "Issues in training effective supervisors," Applied and Preventive Psychology, vol. 3, pp. 27-42, 1994. 